\title{
Two Exceptional Witnesses of Latin American Independence: The Prussian Explorer Alexander Von Humboldt and The Virginian Politician Thomas Jefferson $^{1}$
}

\author{
Dos Testigos Excepcionales de la Independencia \\ Latinoamericana: \\ El Explorador Prusiano Alexander Von Humboldt y el Político \\ Virginiano Thomas Jefferson
}

\section{Dois Excepcionais Observadores da América \\ Latina Independente \\ O Explorador Prussiano Alexander Von Humboldt e o Político Da Virginia Thomas Jefferson}

\author{
Sandra Rebok ${ }^{2}$ \\ The Huntington Library, USA / Consejo Superior de Investigaciones Cientificas, España \\ Grupo de investigación ILAC \\ Sandra.Rebok@csic.es
}

Recepción: 12/03/2013

Evaluación: $1206 / 2013$

Aceptación: 15/05/2014

Artículo de Reflexión

\begin{abstract}
This paper analyzes Alexander von Humboldt and Thomas Jefferson's respective positions regarding the independence of Spanish colonies in South America, as well as the way these views were determined by their own personal experiences. Humboldt is an observer of the political situation just before the beginning of the independence movements. Jefferson is an important actor in both the US independence process and the subsequent creation of a new society. Their respective stands on Spanish America independence movements cannot be studied unrelatedly to the conclusions they draw consequences. This work shows the way both figures discussed these events through the correspondence they exchanged. Last, through these distinguished representatives of the Old and the New World, similarities and differences in the way these political events were addressed from both sides of the Atlantic are also assessed.

Key words: Journal history of the Latin American education, Latin America, Atlantic history, history of ideas, independence movement, Enlightenment.

1 This work has been undertaken under the framework and with financial aid of the research project HAR2010-21333-C03-02, financed by the Ministerio de Economía y Competitividad and within the activities aimed at the dissemination of science carried out at the Vicepresidencia Adjunta de Cultura Cientifica at the Spanish National Research Council in Madrid.

2 Instituto de Historia, Consejo Superior de Investigaciones Científicas (CSIC).
\end{abstract}




\section{RESUMEN}

Este artículo analiza las respectivas posturas de Alexander von Humboldt y Thomas Jefferson en relación con la independencia de los territorios hispanoamericanos y el modo en que estas se hallaban condicionadas por sus propias experiencias: Humboldt, como observador de la situación americana justo antes del comienzo de los movimientos independentistas; y Jefferson, como actor importante en la independencia de los EE.UU. y la posterior creación de una nueva sociedad. Asimismo, no se pueden estudiar sus respectivas posiciones hacia los movimientos independentistas en la América española, desvinculadas de sus conclusiones respecto a la Revolución francesa y sus consecuencias. El trabajo muestra de qué manera los dos personajes comentaron estos sucesos en la correspondencia que mantuvieron entre sí. Finalmente, también se evalúan, a través de estos famosos representantes del llamado Nuevo Mundo y el Viejo Mundo, las diferencias y similitudes en la manera de reaccionar ante estos eventos políticos y sociales desde el punto de vista europeo, en comparación con la mirada desde Norteamérica.

Palabras clave: Revista Historia de la Educación Latinoamericana, independencia, Hispanoamérica, Ilustración, historia atlántica, historia de ideas.

\section{RESUMO}

Este artigo analisa as respectivas posturas de Alexander Von Humbldt e Thomas Jefferson em relação com a independência dos territórios hispano-americanos e o modo em que estas se encontravam condicionadas por suas próprias experiências: Humboldt, como observador da situação americana justamente antes do começo dos movimentos independentistas; e Jefferson, como ator importante na independência dos EEUU e na posterior criação de uma nova sociedade. Assim mesmo, não se pode estudar suas respectivas posições em relação aos movimentos independentistas na América espanhola desvinculadas de suas conclusões a respeito da Revolução Francesa e suas consequências. $\mathrm{O}$ trabalho mostra de que maneira os dois personagens comentaram estes sucessos na correspondência que mantiveram entre si. Finalmente, também se avaliam, por meio destes famosos representantes do chamado Novo Mundo e do Velho Mundo, as diferenças e similitudes na maneira de reagir a estes eventos políticos e sociais, a partir do ponto de vista europeu, em comparação com o olhar norte-americano.

Palavras-chave: Revista História da Educação Latino-americana, Independência, Hispanoamérica, Ilustração, historia atlântica, historia das ideias.

\section{INTRODUCTION}

Two of the many intermediaries participating in the transatlantic communication and transfer of knowledge during the end of the eighteenth and the beginning of the nineteenth centuriesa period characterized by the questioning of the traditional structure of the world and the search for a new social order-were the Prussian traveler and scientist Alexander von Humboldt (1769-1859) ${ }^{3}$ and the Virginian statesman, architect, and naturalist Thomas Jefferson (1743$1826)^{4}$. In spite of their upbringing in two different worlds- Berlin and Charlottesville, or urban

3 Among the latest publications with biographical information about Humboldt in English are: Gerard Helferich, Humboldt's Cosmos. Alexander von Humboldt and the Latin American journey that changed the way we see the World (New York: Gotham Books, 2004); Donald Macrory, Nature's Interpreter: The Life and Times of Alexander von Humboldt (Cambridge: Lutterworth Press, 2010); Nicolaas A. Rupke, Alexander von Humboldt: A Metabiography (Frankfurt: Peter Lang, 2005).

4 Among the considerable number of Jefferson biographies, the following works can be particularly recommended: Richard B. 
Europe versus rural America- there were many affinities between them with regard to their thoughts and actions: both may be seen as leading minds and staunch advocates of the ideals of Enlightenment; they both clearly saw the deficiencies of contemporary European society, as well as the problems the Spanish American colonies were facing; and for both of them the United States served as a hopeful experiment for the application of these ideas, aiming to create a better form of society. However, there are also marked differences in their position on particular topics, as well as in their general understanding of the postulates of the Age of Reason and how to put them into practice. Given their different ideological backgrounds, personal experience and professional positions, they also had distinct approaches to the Spanish American independence movement that they were witnessing and on which they were commenting.

Humboldt and Jefferson had several personal meetings during the Prussian's visit to the United States, which took place in spring of the year $1804^{5}$, when the former finalized his scientific expedition through the Spanish colonial territories in America (1799-1804), divided at the time of his travels into the viceroyalties of New Spain, New Granada, Peru and the island of Cuba. From these personal meetings onwards they established and maintained a close friendship over the following twenty years, marked by a lively exchange of ideas and information, in which they kept each other informed about their respective work, as well as their personal impressions of the pivotal social and political events of their period of time; among these were the independence movement in Latin America and the applicability of the democratic model to this region.

The Virginian and the Prussian shared another common ideal: both were supporters of the reasons and convictions which led to the French Revolution, and initially held hopes for the possible impact of this movement in France as well as in other places, although they in no way approved of the revolutionary fervor and methods of the Jacobins. Nevertheless, as we shall see, the different sociopolitical contexts of the two men, as well as their respective responsibilities, influenced both their argument sand their action. In order to analyze their approach to revolutionary movements in general, and their attitude to aspirations to independence in the Spanish American colonies in particular, it is first of all important to trace the extent to which Humboldt and Jefferson's convictions were molded by their transatlantic experiences. While Thomas Jefferson's ideas for the future of the United States were strongly marked by the time he spent in France in the position of Minister Plenipotentiary (1784-1789) ${ }^{6}$, Humboldt's life in the colonial societies during five years and his visit at the end to the first free nation in America made an impression that had a strong influence on his reflections on politics.

\section{Transatlantic Experiences of Humboldt and Jefferson}

Both Humboldt and Jefferson had only been on the other side of the Atlantic once in their lives, and had remained in their respective "other" worlds for a period of about five years,

Bernstein, Thomas Jefferson (New York: Oxford University Press, 2003); Joyce Appleby, Thomas Jefferson (New York: Times books, 2003); Malone Dumas, Jefferson and his time. 6 vols. (Boston: Little, Brown, 1948-1982); Andrew Burstein, The inner Jefferson. Portrait of a grieving optimist (Charlottesville, London: University of Virginia Press, 1996).

5 A very good, detailed and well-documented description of Humboldt's travels through the United States can be found in: Hermann R. Friis, "Alexander von Humboldtts Besuch in den Vereinigten Staaten von Amerika vom 20. Mai bis zum 30. Juni 1804", in Alexander von Humboldts. Studien zu seiner universalen Geisteshaltung, edited by Joachim H. Schultze (Berlin: Walter de Gruyter\& Co., 1959), 142-195. An English version of this article, limited only to his stay in Washington, is Hermann R. Friis, "Baron Alexander von Humboldt's Visit to Washington". Records of the Columbia Historical Society 44 (1963): 1-35. These articles contain furthermore interesting comments and impressions made by several persons who had met Humboldt.

6 Concerning Jefferson's time in France please see: William Howard Adams, The Paris Years of Thomas Jefferson (New Haven, London: Yale University Press, 1997); James McGrath Morrie and Persephone Weene, eds. Thomas Jefferson's European Travel Diaries (New York: Isidore Stephanus Son, 1987). 
thus allowing them a deeper insight into local society. In Humboldt's case, influenced by his identification with the ideals of the North American independence movement, he was very impressed by the democratic form of U.S. society. Here he observed the model of society that in his opinion represented the future of the Spanish colonies as well as European monarchies. ${ }^{7}$ If we are to understand better his expectations for the United States as a free society, it helps to have a closer look at Humboldt's general attitude towards colonialism. During his unique scientific expedition in the Spanish territories he was able to learn about this system, with all its inconveniences and its problems for the oppressed or enslaved part of the society, just before the independence movements started to arise in those territories. In his numerous publications, and even more in his travel diaries, he also includes some rather critical thoughts on the diverse facets of the colonial system. An extract of an essay on colonies found in his diaries seems particularly revealing, and stands out for the in-depth analysis of its different facets and the possible consequences Humboldt foresees. ${ }^{8}$ Here he condemns the basic concept of colonialism - the idea that one country had to pay tribute to another and that the expansion of prosperity, industry, as well as enlightened ideas remained under that dominating country's control. The document demonstrates that his personal convictions were based on strong moral considerations, and that the well-being and happiness of the people were always foremost in his mind.

Several topics seem to have taken on special relevance for Humboldt during his travels through Spanish America. Besides the horrors of slavery and the injustice as well as the negative consequences of colonialism, such as the bribery of its administrative representatives, he was also concerned about the difficult situation of the Indians, of the missionary system, as well as the treatment of the workers by the big land or mine owners. Nonetheless, the terror of the French Revolution as well as the cruelties committed during the revolt in Haiti ${ }^{9}$ and other slave riots might have played a role in the fact that he very often warned of violent reactions in Spanish America. He recognized that while people were being incited to combat, they could not lead to the construction of a stable society. In his diaries there is thus no explicit comment or advice disclosing his opinion about the claims for liberty of the colonies he visited. His conviction that the Spanish dominions would find themselves in a much more favorable economic situation if they had achieved their independence from the financial interests of the metropolis can only be derived from his detailed economic analyses, his statistics of trade, and his comments on the population. On the one hand, this is because Humboldt had always held a feeling of gratitude towards the Spanish King Carlos IV for granting him generous permission for his expedition

$7 \quad$ Regarding Humboldt's general vision of the United States in comparison to colonial Spanish America, see: Ingo Schwarz, "Alexander von Humboldts Bild von Latein- und Angloamerika im Vergleich", in Nord u. Süd in Amerika: Gegensätze. Gemeinsamkeiten. Europäischer Hintergrund, edited by Wolfgang Reinhard and Peter Waldmann (Freiburg: Rombach, 1992), Vol. 2, 1142-54; Ingo Schwarz, "Alexander von Humboldt-Socio-political Views of the Americas", in Ansichten Amerikas. Neuere Studien zu Alexander von Humboldt, edited by Ottmar Ette and Walther L. Bernecker (Frankfurt a. Main: Vervuert, 2001), 105-116; Sandra Rebok, "A new approach: Alexander von Humboldt's perception of colonial Spanish America as reflected in his travel diaries", Itinerario XXXI, No. 1 (2007): 61-88.

8 Margot Faak, ed., Lateinamerika am Vorabend der Unabhängigkeitsrevolution. Eine Anthologie von Impressionen und Urteilenaus den Reisetagebüchern, Vol. 5 (Berlin: AkademieVerlag, 1982), 63-64. (French original: “D' où vient ce manque de moralité, d’où viennent ces soufrances, ce malaise dans lequel tout homme sensible se trouve dans les Colonies européennes? C’est que l'idée de la Colonie meme est une idée immorale, c'est l'idée d’un pays qu’on rend tributaire à une autre, d'un pays dans le quel on ne doit parvenir quàun certain degré de prospérité, dans lequel l'industrie, les lumière ne doivent se répandre que jusquà un certain point. (...) Tout Gouvernement Colonial est un gouvernement de méfiance. On y distribue l'autorité non selon que la félicité publique des habitants l'exige, mais selon le soupçon que cette autorité peut s'unir, s’attacher trop au bien de la Colonie, devenir dangereux aux intérêts de la mère patrie").

9 The slave revolt in in the French colony of Saint-Domingue, called the Haitian Revolution (1791-1804), was a crucial event that combined considerations of racial aspects as well as social revolution as a means to restructure society, and it is thus interesting to analyze Humboldt's as well as Jefferson's attitude towards these questions. See: Sandra Rebok, "La Revolution de Haïtivue par deux personages contemporains: Le scientifique prussien Alexander von Humboldt etl'homme d’état américain Thomas Jefferson", French Colonial History 10 (2009): 75-95. 
through the American colonies, the realization of his life's goal. Moreover, Humboldt's position was also a function of his self-understanding as a scientist and the personal aims he related to his expedition. In other words, he had quite clearly set his focus on his scientific objectives, and was reluctant to risk realizing his American project. A typical intellectual characteristic of Humboldt, moreover, is that he never limits himself to simply criticizing what he found. Instead, his criticism is based on an in-depth study of these issues, frequently accompanied by specific solutions that seemed more efficient to him or, in some case, simply more humane. In consequence, his writings contain important proposals for specific reforms to be applied in many different aspects, for example, in response to overreliance on the mono-cultivation of sugar and of course, regarding the institution of slavery.

As for Jefferson, his impressions of the other continent, in pre-revolutionary France, were also very complex. He would often dine with many of the city's most prominent aristocrats, but also sided with the protagonists in the 1789 French Revolution, including the Marquis de Lafayette and the Comte de Mirabeau. The considerable number of letters wherein he discussed his contact with the European world illustrates just how decisively those experiences shaped his ideas and convictions about the building of a new form of society. Herein we see clearly his beliefs about liberty, the structure and obligations of the government, and the importance of the ownership of land and property for the prosperity of society. This personal European experience just before the French Revolution, as well as his observation of the subsequent developments, are also crucial if we wish to understand Jefferson's position regarding the Latin American independence movement and his analysis of events. Some of the comments he had made in his early years might lead to the assumption that he would support liberal democratic revolutions in general, and that he also saw the American Revolution as a model for other nations to follow. Furthermore, he himself in the Declaration of Independence of the thirteen colonies in 1776 defended the right of the people to throw off a government that does not fulfill its task of serving the nation.

Nevertheless, Jefferson was frequently critical of other independence movements; he did not view the American case as being easily exportable and applicable elsewhere, and relentlessly argued that the most successful ingredient of any reformist or revolutionary movement was time. Following the idea of the political thinker Montesquieu, Jefferson also believed that state traditions and histories could only change gradually over time, and that imposing new modes and orders on a culture which had no experience with them would inevitably fail, and possibly create a worse state of social affairs. Jefferson deployed an organic metaphor of fruit growing on the stem of the tree: If the fruit needed violent shaking to pry it loose, he warned, it was a signal that it was not mature enough to stand alone; whereas when it was fully ripe, the fruit would fall effortlessly and naturally from the branch ${ }^{10}$.

Already in the context of the French Revolution, he manifested his beliefs and concernsabout this major historical event. His reaction seems to be a rather complex combination of ideals, personal interests, political convictions, and his own experience with the recent American Revolution ${ }^{11}$. To summarize, we can state that whereas at the beginning he was optimistic about the changes in France, he later became more aware of the uniqueness of the American political experiment and expressed this in his letters, pointing out the particular circumstances of the United States that enabled the success of this process. Furthermore, his attitude changed

10 James R. Sofka, "A Commerce Which Must be Protected": The International Policy of Thomas Jefferson, 1785-1809, forthcoming, this material taken from manuscript provided by the author for comment. See also: James R. Sofka, Metternich, Jefferson and the Enlightenment: Statecraft and Political Theory in the early Nineteenth Century (Madrid: CSIC, 2011), 62.

11 Merrill D. Peterson, “Thomas Jefferson and the French Revolution”, The Tocqueville Review 9 (1987/88): 15-25. 
over the years, as a result of subsequent political developments in France, but also due to the evolution of his personal reflections on this topic. Generally speaking we can say that, while he was sympathetic to the basic aspirations of this movement, he argued that France had no experience with liberal republican government and that the autocratic power of monarchy and church were too ingrained in the culture to be ended by a simple declaration of the rights of man. He thus gave the Parisian reformersrather conservative advice, advocating the negotiation of minor arrangements with the King, who would gradually transfer powers to an assembly while retaining enough royal privileges to prevent a counter-reaction.

His analysis of the independence movements in the Spanish-speaking parts of the Western Hemisphere was identical to his conclusions on France and followed a similar logic. In his year of retirement the political situation in the Spanish part of America, and the first signs of the independence movements in these regions, became an important matter for Jefferson. He mentioned this topic to several correspondents in Europe, and remarked on his ideas and fears for the future of these colonial societies, pointing to the disparities between the United States and Spanish America. Among the people to whom he presented his considerations on this matter were for instance the Polish general Andrzej Tadeusz Kościuszko ${ }^{12}$ as well as the writer, economist, and government official Pierre Samuel Dupont de Nemours ${ }^{13}$. Also to his close friend Lafayette he expressed his hopes and misgivings regarding this question: "I join you, sincerely, my friend in wishes for the emancipation of South America. That they will be liberated from foreign subjugation I have little doubt. But the result of my enquiries does not authorize me to hope they are capable of maintaining a free government. (...) they may have some capable leaders yet nothing but intelligence in the people themselves can keep these faithful to their charge (...). A republic of kings is impossible."14 Within the United States, it was mainly with John Adams that he discussed in a candid and revealing correspondence in the period 1817-22 his views of these matters and how they affected U.S. interests in the southern part of America. To Adams he commented in 1818: "I do believe it would be better for them to obtain freedom by degrees only, because that would by degrees bring on light and information and qualify them to take charge of themselves understandingly, with more certainty if in the meantime under so much control only as may keep them at peace with one another"15.

Jefferson did indeed agree with the causes as well as the objectives of these movements, and hoped that their leaders would be able to achieve their goals; but he nevertheless believed that their efforts would ultimately end in military tyrannies, because he did not consider these nations prepared or sufficiently enshrined in democratic structures for self-government. Though he predicted success for the revolutions in the short term, he was skeptical about their consolidation into workable democratic states, since he considered their objectives incompatible with the cultures of the states they ruled. Without the firmly-rooted organs of an independent legislature, judiciary, freedom of the press, and secular law he believed that after a short time the politics in these states would revert to pre-revolutionary patterns, just as Napoleon had revived some of the authoritarian traditions and centralized power of the Bourbons ${ }^{16}$.

It is obvious that for both of these men, their time on the other side of the Atlantic was crucial to the shaping of their social and political thinking. The aspects of their respective 'other' worlds

\footnotetext{
12 Jefferson to Kósciuszko, April 16, 1811, in: Barbara B. Oberg and J. Jefferson Looney, eds, The Papers of Thomas Jefferson Digital Edition (Charlottesville: University of Virginia Press) 2009, vol. 3, 565.

13 Jefferson to Dupont de Nemours, April 15, 1811, in: Oberg, "The Papers", 560.

14 Jefferson to Lafayette, November 30, 1813.Thomas Jefferson Papers, Library of Congress.

15 Jefferson to Adams, May 17, 1818, Thomas Jefferson Papers, Library of Congress.

16 Information taken from the manuscript provided by Sofka (forthcoming).
} 
Two Exceptional Witnesses of Latin American Independence: The Prussian Explorer Alexander Von Humboldt and The Virginian Politician Thomas Jefferson

that occupied them most depended on their ideological background, as well as on their personal interest and the position they held in their own societies: for Humboldt these issues were mainly connected to his concept of liberty, including personal, political, and economic freedom, and with all the phenomena linked to them, such as colonialism and slavery. For Jefferson, his observations stimulated the desire to create a government that would provide happiness to his fellow countrymen, since in Europe he was able to observe the consequences of a political system that he profoundly rejected. Thus, for him the challenge was to analyze the possibilities that would help to avoid the deplorable state of affairs he experienced during his time in the Old World, and upon his return, to make those hypothetical ideas into realities.

\section{Humboldt's and Jefferson's correspondence regarding Spanish America}

Over time Humboldt took care to keep Jefferson--and with him the New World--informed about the progress of his research and the writings he published about his American expedition. The Virginian, for his part, seemed to enjoy sharing with his friend the topics he was interested in or worried about, since he very much appreciated the Prussian's expertise and experience in relation to these issues. Thus their personal meeting marked the beginning of a mutually enriching scientific and political transatlantic dialogue between the rising new country and the evolving old, in which they also discussed matters concerning Spanish America ${ }^{17}$.

In Jefferson's answer to Humboldt's perfectly designed and extremely diplomatic letter of introduction to him, written on 24 May 1804, he already revealed a certain interest in this region: "The countries you have visited are of those least known, and most interesting, and a lively desire will be felt generally to receive information you will be able to give. No one will feel it more strongly than myself because no one perhaps views this new world with more partial hopes of its exhibiting an ameliorated state of the human condition"18. There are two aspects of this letter at which we should look more closely: first, it might be surprising that Jefferson calls the Spanish American countries "the least known", in spite of the large number of books that had already been published by various authors on those regions. Several of these books formed part of his own library: In a letter sent by Jefferson in 1787 to the Mexican Miguel Lardizábal y Uribe $^{19}$, who later became a member of the Consejo de Regencia in the court of Cádiz, he adds a list of books relative to Spanish America that were in his possession at that moment, as well as an enumeration of those publications he still wished to acquire. We therefore know that in that year there were already thirteen books related to this region in his personal library, written by authors such as Antonio de Ulloa, Francisco López de Gómora, Jorge Juan y Santacilia, Antonio de Solís y Rivadeneyra and Gabriel de Cárdenas y Cano ${ }^{20}$.

Regardless of this fact, in his last letter to Humboldt, drafted in 1817, Jefferson pointed out that Humboldt's publications on the Southern American region had come at a perfect moment to "guide our understandings in the great political revolution now bringing it into prominence on the stage of the world", and he still calls these territories "a country hitherto so shamefully unknown". This may be meant as a rhetorical expression to underscore the relevance of Humboldt's writings, but it is nonetheless surprising that he seems to ignore or

17 A good analysis of the correspondence between Jefferson and Humboldt, and particularly this letter offers Ingo Schwarz, "From Alexander von Humboldt's Correspondence with Thomas Jefferson and Albert Gallatin", Berliner Manuskripte zur Alexander-vonHumboldt-Forschung 2 (1991): 1-20.

18 Jefferson to Humboldt, May 28, 1804, published in Schwarz, 2004, 91-92.

19 Jefferson to Miguel Lardizabel y Uribe, July 6, 1787, in: Oberg and Looney, 553-554.

20 Ponce interprets and criticizes this as Jefferson's lack of knowledge and interest regarding the Hispanic territories: Esteban Ponce, "Fragmentos de un discurso no amoroso: Thomas Jefferson y la América Hispana. Una aproximación a las relaciones sur-norte", Procesos. Revista Ecuatoriana de Historia 30 (2009): 5-24. 
at least undervalue the numerous previous works. The other aspect to note is the fact that in this first letter Jefferson sent to the Prussian explorer, he already made a reference to the human conditions in Spanish America, which he would like to see "ameliorated".

The situation in the Spanish part of America was a topic they would discuss over the course of many years, since both of them were very concerned about its political future and especially the applicability of democratic models to this region. They were thus interested in knowing each other's respective opinion regarding the independence movement. In an interesting and revealing letter, written in 1811, Jefferson first comments on the importance of the fact that Humboldt's publications came out at a moment "when those countries are beginning to be interesting to the whole world", when they were becoming "the scenes of political revolution" in order to be "integral members of the "great family of nations". Then he expresses his personal doubts: "What kind of government will they establish? How much liberty can they bear without intoxication? Are their chiefs sufficiently enlightened to form a well-guarded government, and their people to watch their chiefs? Have they mind enough to place their domesticated Indians on a footing with the whites? All these questions you can answer better than any other". To some of these questions Jefferson provided some suppositions of his own in order to get a sense of Humboldt's opinions: "I imagine they will copy our outlines of confederation and elective government, abolish distinction of ranks, bow the neck to their priests, and persevere in intolerants. Their greatest difficulty will be in construction of their executive. I suspect that, regardless of the experiment of France, and of that of the United States in 1784, they will begin with a directory, and when the unavoidable schisms in that kind of executive shall drive them to something else, their great question will come on whether to substitute an executive elective for years, for life, or an hereditary one. But unless instruction can be spread among them more rapidly than experience promises, despotism may come upon them before they are qualified to save the ground they will have gained"21.

In his answer to this letter several months later, the Prussian expressed his concerns about these matters and responded to Jefferson's reflections. Nevertheless, though the letter itself was quite extensive, his comments on the issues mentioned were much less detailed. Humboldt only pointed out his keen interest in the struggle in Spanish America and predicted a violent conflict, which would leave its imprint on the social order, since for three centuries European society had been based on mutual resentments and animosity ${ }^{22}$.

Two years passed before Jefferson replied- because of the war with England, getting mail to and from the Continent could take a long time-but we can see that Jefferson was still intrigued by the events in Spanish America. In this answer it becomes evident that he was aware of the limitation of the applicability of the democratic system established in the United States to other American colonial societies, especially to those regions that were under the influence of the Catholic religion: one major difference he saw compared to his country. In this new letter he illustrated the progress of his thoughts and took a rather skeptical view of the situation and the practicability of the movement in the long term. Particularly remarkable in this manyfacetted analysis are his political predictions as well as his critical reflections on the role of religion in this process: "History, I believe, furnishes no example of a priest-ridden people maintaining a free civil government. This marks the lowest grade of ignorance, of which their

21 Jefferson to Humboldt, April 14, 1811, published in Schwarz, 2004, 119-121.

22 Humboldt to Jefferson, December 20, 1811, published in Schwarz, 122-123 (French original: "Je suis vivement intéressé comme Vous à la grande lutte de l'Amérique espagnole. Il faut pas sétonner que la lutte soit sanglante, lorsqu'on pense que les hommes portent par tout l'empreinte de l'imperfection des institutions sociales et que les peuples d'Europe depuis trois siècles ont cherché leurs sécurité dans le ressentiments mutuel et la haine des Castes"). 
civil as well as religious leaders will always avail themselves for their own purposes. The vicinity of the New Spain to the United States, and their consequent intercourse, may furnish schools for the higher, and example for the lower classes of their citizens. And Mexico, where we learn from you that men of science are not wanting, may revolutionize itself under better auspices than the Southern provinces. These last, I fear, must end in military despotisms. The different cast of their inhabitants, their mutual hatreds and jealousies, their profound ignorance and bigotry, will be played off by cunning leaders, and each be made the instrument of enslaving others. But of all this you can best judge, for in truth we have little knowledge of them to be dependent on, but through you" ${ }^{23}$.

A few years later, in 1817, when it was easier to see which direction the events in the former Spanish colonies were taking, he continued to express his concerns on their preparation for self government: "The issue of it's struggles, as they respect Spain, is no longer a matter of doubt. As it respects their own liberty, peace \& happiness we cannot be quite so certain. Whether the blinds of bigotry, the shackles of the priesthood, and the fascinating glare of rank and wealth give fair play to the common sense of the mass of their people, so far as to qualify them for self government, is what we do not know ${ }^{\prime 24}$. In the same letter, which was the last one he addressed to Humboldt, Jefferson was very clear regarding the conditions to be fulfilled before a revolution could be successful in the long term: "The first principle of republicanism is that the lex majoris partis is the fundamental law of every society of individuals of equal rights: to consider the will of the society enounced by the majority of a single vote as sacred as if unanimous, is the first of all lessons in importance, yet the last which is thoroughly learnt. This law once disregarded, no other remains but that of force, which ends necessarily in military despotism. This has been the history of the French revolution; and I wish the understanding of our Southern brethren may be sufficiently enlarged and firm to see that their fate depends on it's sacred observance".

What may be surprising in this context is the fact that, whereas Jefferson also expressed to other European correspondents than Humboldt his concerns regarding these events and their possible future, he nevertheless did not seem to be interested in establishing a dialogue with the protagonists of the independence movements in Spanish America, as Humboldt for instance had done with the Venezuelans Andrés Bello and Simón de Bolívar, the Ecuadorian Vicente Roca Fuerte and the Mexican Lucas Alamán25. Here we can sense that Jefferson seemed to maintain a certain distance from these leaders, unlike what he did in the case of the French Revolution.

As we have seen in the above cited letters, Jefferson considered Humboldt an expert on this topic - after having been an eye-witness during his scientific expedition through these territories - and he shared his doubts with him. Moreover, Jefferson knew of Humboldt's political influence among intellectuals in the French capital. This is another explanation of his extensive discussion of the future of Latin America and his comments on the role of the United States. Finally, Jefferson was also aware of the Prussian's crucial significance regarding the dissemination of a positive image of his country overseas, through Humboldt's contacts and correspondence with the most prominent personalities in Europe. He was perfectly conscious of his friend's sympathy for the United States in general and the American project in particular, and to a certain extent he may have seen him as an ally in his attempt to put enlightened ideas into practice to establish a new form of society in the New World. The fact

23 Jefferson to Humboldt, December 6, 1813, published in Schwarz, 130-33.

24 Jefferson to Humboldt, June 13, 1817, published in Schwarz, 145-146.

25 Ponce, "Fragments", 19. 
that our traveler had himself witnessed the social oppression existing in colonial societies of Spanish America, and had personally lived in several European monarchies which displayed all the social injustices Jefferson sought to overcome in the new form of society he was trying to create, made him an interesting interlocutor. Last but not least, Humboldt's enthusiastic letters, containing very positive impressions of the United States, also contributed decisively to his importance for the Virginian, since in them he also transmitted to the Old Continent his personal reflections concerning this young republic.

\section{FINAL CONSIDERATIONS}

In spite of Humboldt's special consciousness of fundamental principles regarding liberty and equality and his consequent severe criticism of colonialism, he never expressed himself in favor of a military solution, as he rejected all kind of violent revolutions for political ends. Instead he preferred extensive reforms of Spanish colonial politics, hoping that these measures might avoid more vehement future conflicts. In Jefferson's case, his attitude towards these revolutionary events was more complex and more conditioned by the political and social circumstances he lived in. Given the fact that during the years 1801-1809 he was the president of the United States, his political thoughts may not only have been guided by his personal convictions, but depended on a constellation of divergent interests. Those years saw major changes in the interior and exterior politics of his country, which also had an influence on Jefferson's position.

Contrasting the respective positions of Humboldt and Jefferson, one must be conscious of the different function they occupied in their respective societies: as a scientist, Humboldt could approve the aims and the political results of the Revolution- rejecting all its violent aspects- and publicly express his opinion, since its goals and results were in line with his own convictions. Jefferson, on the other hand, was obliged in his position to consider and weigh up all possible consequences of his measures in terms of the interest of his country, the reactions of his enemies and finally the influence of his actions on the next elections.

Finally, as for the humanist values and the equality among men postulated in the context of the Enlightenment, they also represent to a certain extent the differences between the Old and New Worlds, and thereby the manner and the extent to which these postulates were to be realized. Whereas Humboldt showed a more idealistic position and applied his convictions to all people, in Jefferson's attitude, on the other hand, we find a more pragmatic and complex understanding of his own stated values. Here, then, we close the circle and return to our initial arguments expressed at the beginning, where we introduced both of them as representatives of the ideas of the Age of Reason. We need to be aware that these did not consist of exactly the same postulates, values or priorities in the respective worlds they were brought up. The societies in which they were educated had distinct needs or priorities and offered other possibilities or solutions- thus part of the different interpretation of this movement by Humboldt and Jefferson may be explained by these considerations. 
Two Exceptional Witnesses of Latin American Independence: The Prussian Explorer Alexander Von Humboldt and The Virginian Politician Thomas Jefferson

\section{REFERENCE}

Adams, William Howard. The Paris Years of Thomas Jefferson. New Haven, London: Yale University Press, 1997.

Appleby, Joyce.Thomas Jefferson. New York: Times books, 2003.

Bernstein, Richard B. Thomas Jefferson. New York: Oxford University Press, 2003.

Burstein, Andrew. The inner Jefferson. Portrait of a grieving optimist. Charlottesville, London: University of Virginia Press, 1996.

Dumas, Malone. Jefferson and his time. 6 vols. Boston: Little, Brown, 1948-1982.

Faak, Margot. ed. Lateinamerika am Vorabend der Unabhängigkeits revolution. Eine Anthologie von Impressionen und Urteilen aus den Reisetagebüchern, vol. 5. Berlin: Akademie Verlag, 1982.

Friis, Hermann R. "Alexander von Humbold ts Besuch in den Vereinigten Staaten von Amerika vom 20. Maibiszum 30. Juni 1804". In Alexander von Humboldt. Studien zu seiner universalen Geisteshaltung, edited by Joachim H. Schultze. Berlin: Walter de Gruyter \& Co., 1959, 142-195

Friis, Hermann R. “Baron Alexander von Humboldt's Visit to Washington". Records of the Columbia Historical Society 44 (1963): 1-35.

Helferich, Gerard. Humboldt's Cosmos. Alexander von Humboldt and the Latin American journey that changed the way we see the World. New York: Gotham Books, 2004.

Macrory, Donald. Nature's Interpreter: The Life and Times of Alexander von Humboldt. Cambridge: Lutterworth Press, 2010.

McGrath Morrie, James and Persephone Weene, eds. Thomas Jefferson's European Travel Diaries. New York: Isidore Stephanus Son, 1987.

Oberg, Barbara B. and J. Jefferson Looney, eds. The Papers of Thomas Jefferson Digital Edition. Charlottesville: University of Virginia Press, 2009.

Peterson, Merrill D. "Thomas Jefferson and the French Revolution". The Tocqueville Review (1987/88): 15-25.

Ponce, Esteban. “Fragmentos de un discurso no amoroso: Thomas Jefferson y la América Hispana. Una aproximación a las relaciones sur-norte". Procesos. Revista Ecuatoriana de Historia 30 (2009): 5-24.

Rebok, Sandra. "A new approach: Alexander von Humboldt's perception of colonial Spanish America as reflected in his travel diaries". Itinerario XXXI, No. 1 (2007): 61-88.

Rebok, Sandra, "La Revolution de Haïti vue par deux personnages contemporains: Le scientifique prussien Alexander von Humboldt et l'homme d'état américain Thomas Jefferson". French Colonial History 10 (2009): 75-95.

Rupke, Nicolaas A. Alexander von Humboldt: A Metabiography. Frankfurt: Peter Lang, 2005.

Schwarz, Ingo. "From Alexander von Humboldt's Correspondence with Thomas Jefferson and Albert Gallatin". Berliner Manuskripte zur Alexander-von-Humboldt-Forschung 2 (1991): 1-20.

Schwarz, Ingo. “Alexander von Humboldts Bild von Latein- und Angloamerika im Vergleich In Nord u. Süd in Amerika: Gegensätze. Gemeinsamkeiten. Europäischer Hintergrund, edited by Wolfgang Reinhard and Peter Waldmann, vol. 2, 1142-54. Freiburg: Rombach, 1992. 
Schwarz, Ingo. "Alexander von Humboldt--Socio-political Views of the Americas". In Ansichten Amerikas. Neuere Studien zu Alexander von Humboldt, edited by Ottmar Ette and Walther L. Bernecker. Frankfurt a. Main: Vervuert, 2001, p. 105-116. Schwarz, Ingo, ed. Alexander von Humboldt und die Vereinigten Staaten von Amerika. Briefwechsel. Berlin: Akademie Verlag, 2004.

Sofka, James R. Metternich, Jefferson and the Enlightenment: Statecraft and Political Theory in the early Nineteenth Century. Madrid: CSIC, 2011.

Sofka, James R., "A Commerce Which Must be Protected”: The International Policy of Thomas Jefferson, 1785 -1809 (forthcoming).

Rebok, Sandra. "Two Exceptional Witnesses of Latin American Independence: The Prussian Explorer Alexander Von Humboldt and the Virginian Politician Thomas Jefferson". Revista Historia de la Educación Latinoamericana. Vol. 16 No. 23 (2014): 205 - 216. 